\title{
An Analysis of Historical and Political Evolution of Kashmir State
}

\author{
Aijaz Ahmed Shaikh \\ PhD Scholar \\ Department of International Relations, \\ University of Karachi \\ aijazshaikh@salu.edu.pk \\ Safdar Ali \\ Ph.DScholar \\ Institute of International Relations \\ Shah AbdulLatif University, Multan \\ safdarali@bzu.edu.pk
}

\begin{abstract}
The innocent people of Jammu and Kashmir ( $J \& K)$ continuously struggled for the protection of their lives. In most of the areas which are under the administrative control of Indian Military, the survival of Kashmiris is becoming more challenging due to the imposed social, political and economic sanctions posed by the Indian government. The first part of this paper examines the historical legacy of Kashmir and the middle of the paper attemp ts to highlight how the people are demanding their rights as well as freedom from the Indian troops. Even thou, the international media has highlighted and unveiled the true picture of Indian brutality and the open murder of Kashmiri public. But, unfortunately the world community is still salient and watching the cruel actions taken by the Indian forces in the valley. Overall, this paper attempts to highlight the analytical approach about the history, status, equity and struggle of freedom of the Kashmiris.
\end{abstract}

Keywords: Historical, Kashmir, Political, British, India \& Pakistan

\section{Historical Mechanism}

At the point when British left our country in 1947 it was generally expected that the two replacement states, India and Pakistan, would team up to save the basics of what seemed, by all accounts, 
to be the best of all British accomplishments in the subcontinent, a brought together nation. The heads of the two new systems had experienced childhood in a similar custom. They had cooperated in the military and the common assistance and they shared a typical legacy of British political, legal managerial, moral and instructive ideas. This, it appeared to numerous eyewitnesses in the late spring of 1947, may in any case be saved underneath the umbrella of a solitary Governor-General and a solitary Commander-in-Chief. The gadget of Pakistan could maybe fulfil Muslim yearnings without annihilating the basics of solidarity. At the end of the day, the final product of the transfer of power from Great Britain to India and Pakistan could be the development of some sort of bureaucratic construction, but maybe less formal over had been planned by some who had wrestled with the issues of Indian freedom since the primary long stretches of the twentieth century, especially those British parliamentary sketchers who formulated the administrative arrangements of the 1935 Government of India Act. The truth, nonetheless, has been something totally different (Talbot, 2016). India and Pakistan since the exact instant of their introduction to the world have become ever further separated; and their arrangements both homegrown and worldwide have advanced in progressively unique ways. One basic justification behind this, maybe, to be sure, the most significant, is without a doubt to be found in the outcomes of the argument about ownership of the State of Jammu and Kashmir. It is conceivable, to be sure likely, that without Kashmir the predeterminations of India and Pakistan would have regardless separated; however Kashmir sped up the cycle and added to it a most unwanted level of savagery. It very well may be contended that Kashmir has been the predominant power in moulding the international strategies of the two India and Pakistan; and there can be no question that it has contaminated each part of the inner political existence of the two countries (to which, in 1971, was added a third, Bangladesh). Basically the idea of the Kashmir debate is genuinely straightforward; however the intricacies of its subtleties are without a doubt considerable. The Indian Princely State of Jammu and Kashmir, with a transcendently Muslim populace under a Hindu Maharaja, was so arranged topographically that it might have joined either Pakistan or India following the British takeoff from the subcontinent in 
1947. The rationale behind the segment of the Indian Emp ire in to Muslim and non-Muslim parts recommended that Kashmir should go to Pakistan. In the occasion, the Maharaja chose to consent to India. His choice was upheld obviously by Indian arms and tested, fairly less unmistakably from the get go, by the arms of Pakistan. This occurred against the foundation of the British retreat from Empire in 1947; and there can be no question that had the British settled on various choices as to strategy and game-plan around then the Kashmir issue may never have emerged, essentially in its intensely destructive structure.

\section{Manifesto of 'Naya Kashmir'}

The assertion characterized the need or significance of annulling manipulative landlordism without remuneration, liberating turn ers by conceding them lands they chipped away at and building up cooperatives. It was additionally resolves issues of sex, and initiating instructive and social plans for underestimated segments of the general public. The National Congress coordinated effort with the congress was a reason for festivity for individuals of India yet it was absolutely an abomination for the Pakistan and individuals of Pakistan. In 1947 the public congress secured its elf as a specialist of the political activation. The idea of new Kashmir proclamation agent to the obligation of the locale and towns. In September 1944, delegates of the association planned and apply a statement specifically as 'Naya Kashmir'. New Delhi viewed Kashmir as an authentic piece of the Indian Union. Naya Kashmir pronouncement was:

- It was a program of democratization and reformist social change under the new system.

- It was concluded that Urdu the most widely used language that would control connect the bay among Kashmiri and Dogri talking portions of the state.

- The ruler would be a more nominal leader.

- Naya Pakistan pronouncement was to make a more democratic and capable type of the public authority.

The new government was going by the sheik Mohammad Abdullah and Mirza Afzal Beg passes the milestone which implies it is law "land to the turner" enactment, 1950. In mid July 1950, the new 
government was going by Sheikh Mohammad Abdullah settled on a milestone choice. This was in the blessing of individuals of Kashmir. New Kashmir proclamation's motivation is to offer rights to individuals of Kashmir. The incomparable assurance of our relationship with the state India is the character of mainstream and Democratic desires, which have directed to individuals of India just as to those individuals of Jammu and Kashmir in their battle and difficult work and furthermore their penances. Ladies resident will granted same rights and equivalent rights to every one of them. Business will as granted similarly to all kinds of people equivalent it depends on equivalent privileges of ladies. New or Naya Kashmir is put together and cantered with respect to approach privileges of ladies in the general public. Naya Kashmir declaration depended on this thought. Naya Kashmir is the philosophy through which they need to make another arrangem ent of state. Kashmir is taken care of Indian state and armed force.

\section{Kashmiriyat}

Kashmiriyat is a different point of view for individuals of the region in the province of Jammu and Kashmir. From the ages, Muslims, Kashmiri Pandits, Dogras, and Ladakhsis they have tired consistently to frame a public cognizance or mindfulness to name a social integrity in country. The kashmiriyat was developed by Sheikh Abdullah's National Congress. Which included aggregate social pieces from an envisioned past that would enclose both the Pandits and the Muslim of the state. The rationale of kashmiriyat was produced by my maternal granddad Sheikh Mohammad Abdullah, was not given over to me as an impossible and imperceptible or dynamic build, in actuality, it was medieval battle.

- Kashmiriyat was advocated in 1940s and 1950s to overcome the incorporating techniques of progressive systems of free India.

- Kashmiriyat was the common philosophy of Sheikh Mohammad Abdullah.

- Kashmiriyat expressed for individuals of Kashmir.

Kashmiris are confronting a ton issue to again their opportunity and sway (Peer, 2010). Kashmiri are step by step losing lives of their kin however Indian armed force and their administration 
couldn't care less with regards to this is on the grounds that they need Kashmir as the piece of Indian state on account of their this interest Kashmiris are forfeiting their lives yet it doesn't matters to India. The idea of this critical doesn't endeavour to work on the vagueness and intricacy of the strict, social, and social characters. Mridu Rai said that this embrace of a mainstream philosophy of Kashmiriyat read through a common recorded history, it was expected likewise as an approach to keep under control middle in Delhi that had started to infringe upon Kashmiri self-rule progressively during the $1950 \mathrm{~s}$. Yet, the provincial notions that are so all around settled in the mind or brain science of individuals, this endeavour or work is as yet in an unpredictable stage.

\section{Equity and Freedom}

During the imperious principle of the Dogra ruler or maharajas there was a tenacious provincial inclination against Kashmiri Muslims who were living in Kashmir. With no admittance to the cutting edge training, Muslim took sank into a profound destruct of the standard under the Dogra Hindus. Kashmiriyat procedure was improvement to offer rights to individuals of the Kashmir which is their right. Kashmiriyat arrangement of the constituent Assembly of Jammu and Kashmir to systematize the constitution of the state in 1951. They are individuals of Kashmir who need equity and opportunity and they all are notable as kashimiriyat in light of the fact that they are individuals of Kashmir. They are battling for opportunity and autonomy which is essential right of all individual on this planet.

It is the primary wish surprisingly of the Kashmir to get autonomy from all controls and fears they need freedom from control of India and Indian armed force. By 1947 the autonomy of the sub mainland was guaranteed. Autonomy is the essential column to make an express, a solid state. In the mid of February the British government declared it unmistakable aim or intention to make vital strides to impact the transaction of the force in Indian hands before June 1948. Thus, advance to keep the sub mainland to gether was as an alliance had finished with the disappointment of the bureau Mission plan of 1946.

The concept or thought process of Pakistan, the fantasy, the fabrication, an ambiguous 'plot' was to become reality. Pakistan 
was dream of that load of individuals who was wished to have a different country and where opportunity is outright. Kashmiri additionally needs a land parcel where that their all traditions and customs uninhibitedly with no control. They need be free and need their autonomous at any expense they are forfeiting their lives to get autonomy and freedom which is fundamental right of all individual of this world. Pakistan was given by the triumph, Lord Wavell, in 1946. It was known as the "Breakdown Plan" his idea was to offered freedom to more homogeneous space of the focal and southern India while keeping up with the British presence in the Muslim greater part region in the north west and north east, where Muslim are in gigantic sum. Individuals of Kashmir need independence from fear of India and they need to end this conflict. Many individuals of Kashmir lost their lives for opportunity and autonomy. This conflict will end when India will end this conflict and leave Kashmir free.

In March 1947, Lord Wavell was supplanted as the triumph by Rear-Admiral Lord Louis Mountbatten (Campbell-Johnson, 1985), whose brief from P.M Attlee was to acquire a unitary government for the British India and the Indian states, if conceivable. Before long Mountbatten resuscitate the Cabinet Mission plan. The scene here is one of un-remembered unhappiness. At this beginning Phase I can see minimal normal or same ground on which to assemble any concurred answer for the issue for the future for India. On $3^{\text {rd }}$ June, British government made an arrangement for the segment of the sub mainland. On eighteenth July the Indian Independence Act was passed. Kashmiris are extremely cherishing individuals and furthermore exceptionally mindful however they confronting a ton issues to acquire their opportunity and autonomy. The desire to move quickly was uplifted by some thoughtful unsettling influence and mobs between networks, which were reached to terrifying extents in about a few regions, exceptionally in Punjab which lined the territory of Jammu and Kashmir. As Muslims and Hindus can't live respectively, the two of them need separate country similarly Kashmir additionally need freedom to satisfy their ceremonies and customs. Kashmir is exceptionally devout land henceforth it needs its autonomy. Kashmiris are not liberal as a state but rather the inquiry ascend here is the reason Kashmir isn't a state and why it isn't perceived as a state? As we 
realize that Kashmir has an area, government yet it don't have sway which is considered as the mainstay of a state one request to make an express these three column are extremely fundamental they are following:

- Territory

- Government

- Sovereignty.

This is the explanation that Kashmir isn't considered as a state and why it isn't free. Through history it appears now and then to move with the limitless gradualness of an ice sheet and now and then to rich forward in a deluge: It was According to Lord Mountbatten. He was the triumph around then India and Pakistan or we van Hindu and Muslims was independent and having separate country.

\section{Free Kashmir}

It is motto of individuals to free Kashmir (Bose, 2003). India involved Kashmir to acquire control and get more fortify. The insurrection has likewise influenced the existences of Azad Kashmiris, who are still today sitting tight for their own sacred position. In November 1995, Mirwaiz Omar Farooq meet Sardar Qayum in New York. He concurred and said Omar Farooq that the All Parties Hurriyat Conference ought to address them too at the worldwide level. In this gathering it was expressed that people acknowledge in conclusive terms the administration from the valley.

Azad Kashmiris have been thoughtful to the Kashmiris of the valley where many actually have family members. An alternate liberation cell has been working in Muzaffarabad which is said to be a key player in Kashmir since late 1980s, which stay shut connections with AJK government in Muzaffarabad and furthermore in Islamabad. Kashmir is until battling for their opportunity. A radio station has additionally been working and performing since 1960 to raise the local voice of public.

In 1989, Azad Kashmir Radio station changed its projects timetable to dispose of the engaging viewpoints and furthermore rousing projects identified with opportunity battle from Radio Pakistan. Kashmiris from the valley currently have made some contact between Kashmiri speakers from the valley, those likewise 
individuals who are Poonch and Rawalakot locale. This radio station is conveying data to individuals of Kashmir. It is helping them in resolving their domestic issues. Some areas of Jammu and Kashmir are still in pressure as well as their general tradition of freedom. Majority of the individuals of Kashmir needs:

- Traditional freedoms

- Security

- Kashmir as a state

- Political power

- Democracy

These are the main points that Kashmiris need to spend a happy and prosperous life and they want to get at any expense and for this reason they are forfeiting their lives. There are such incredible associations which are working for insurance of privileges of men.

\section{Inside Jammu and Kashmir 1947 to 1965}

On 27th October 1947, it was the day when Indian Army formally interceded in the Kashmir question, Jawaharlal Nehru (Brown, 2003) sent the accompanying messages to Liaquat Ali Khan who was the Prime Minister of Pakistan around then said he should jump at the chance to clarify that the inquiries of supporting Kashmir in this crisis circumstance isn't planned in any capacity to influence the state to acquiesce to India. Our perspective which we have over and over made public is that the topic of promotion in any contested state or country must ne chose as per the desires or wants of individuals and we stick to this view.

After four days Jawaharlal Nehru announced that our af firmation that we will pull out our soldiers of fighters from Kashmir when harmony and request re-established and leave the choice in regards to the impending fate of the state to individuals isn't only a promise to your Pakistan Government yet in addition to individuals of Kashmir and to the world. Jawaharlal Nehru additionally rehashed this in broadcast on All India Radio on $2^{\text {nd }}$ November 1947. The assertion of Nehru leaves one in no question at all that at this troublesome snapshot of Indo-Pakistani argument about title to the province of Jammu and Kashmir. Joined Nations Security Council has settled (21 ${ }^{\text {st }}$ April 1948) to suggest that the public authority of India and Pakistan should be take sure measures suitable to make 
free province of Jammu and Kashmir. Sheikh Abdullah emergency government which the Maharaja declared toward the finish of October 1947 was a common assortment of authority. Mahajan was as yet the Prime Minister of the state.

The State High Court had been kept from working huge number of authorities in the Maharaja's old organization framework including the Governor of Jammu had been confined. Sheikh Abdullah's political philosophy was a particularly communist, even Marxist. Communist is the philosophy through which state is working and it depends on privileges of freedom and equivalent appropriation of riches. In March 1953 Sheikh Abdullah had implemented an upheaval in the landholding example of the state. One board in the foundation of the National Congress during the hour of Quit Kashmir fomentation of 1946 had been the annulment of the Dogra tradition, its explanation was Sheik Abdullah and his partners. The time being the Sheikh Abdullah emergency or interims system would of need by subjective, undeniably more thus, for sure than anything over which Maharaja presented the 1934 and 1939 Constitution. Constitution assumes exceptionally fundamental part to make a solid state and furthermore a serene state. The Basic program had effectively been laid out by the National Conference in 1944 in a statement entitled or specifically known as New or Naya Kashmir Manifesto. All conditions of this world are talking on the side of Kashmir and individuals of Kashmir yet India isn't halting to persecuting Kashmiris they are disregarding their privileges to make Kashmir as a component of Indian State. India and Pakistan both are checking out Kashmir since it is exceptionally lovely. Recent intentions of Pakistani government are showing serious and favourable steps for Kashmiri public in order to set their prosperous future.

\section{First Kashmir War and Intervention of the United Nations (1947 to 1964)}

The information on the ancestral attack quickly persuaded Mountbatten that is proof of sharpness of Jinnah. The province of Jammu and Kashmir was legitimately and talking a now Indian area. On the Pakistan side Muhammad Ali Jinnah, the public authority general of Pakistan and Liaquat Ali Khan was the Prime Minister of the Pakistan additionally found in Kashmir emergen cy 
proof of a scheme. The armed forces of India and Pakistan were around then still under a similar preeminent order. Since $27^{\text {th }}$ October and the Indian acknowledgment of the state Jammu and Kashmir promotion obviously any Pakistani military activity in the state would be immediate struggle with India. Indian position which Lord Mountbatten put to Mohammad Ali Jannah on first November 1947, and which Indian individuals, no inquiry of Indian powers leaving the province of Jammu and Kashmir until tribesman Mohammad Ali Jannah rehashed Indian requests that he stop to the guide and abet the aggressors. Mohammad Ali Jannah dismissed the proposition of Jawaharlal Nehru (Jalal, 1985). Last month of 1947, undeniable level Indo Pakistani discussions neglected to settle the emergency, Indian soldiers were prevailed with regards to crushing the spirit of the ancestral hostile and security of their own hold over Srinagar. Joined Nations association is working for assurance of human rights and human security from their issue with different nations. The principle thought process of United Nation Organization is to maintain harmony on the planet a settle question among states.

The climate of outrageous common doubt Lord Mountbatten, upheld by the Lord Ismay, was went to Lahore on first November to examine the Kashmir emergency with Quaid-e-Azam Muhammad Ali Jannah and Prime Minister of Pakistan Liaquat Ali Khan. In this gathering M.A Jannah recommended that the issue or question of Kashmir can be settled through United Nations Organization. As U.N is working for government assistance of person and shielding them from war and furthermore from perilous wellbeing sicknesses.

\section{Second Kashmir War (1965)}

In 1960, the President of Pakistan was Ayub Khan. He was contemplating the chance of some sort of joint Info-Pakistani guard game plan that was British dream in the Lord Mountbatten time. During the Sino-Indian emergency in 1962, Pakistan conduct with India was totally antagonistic and unforgiving. The main explanation quickly disintegration Indo-Pakistani relations without a doubt lay in the expanding proof from 1963 onward India planned. In 1963 on eleventh October resigned Prime Minister of Kashmir, Bakshi Ghulam Mohammad reported a few changes in 
the Constitution of the State, Kashmir, which were to turned out essentially inside state in February, 1964.

It is conceivable that in 1964 after the break of shared unsettling influences in the Jammu and Kashmir as well as in India and East Pakistan. There is no answer for the issue of Kashmir by Sheik Abdullah. Jayaprakash Narayan offered his viewpoint in two articles, which were very interesting. According to his view point, our extraordinary chance is Kashmir (Schofield, 1996), and the need to re-examine which the Hindustan Times distributed on twentieth April and fourteenth May 1964. He was derisive of the earnestly of much that India had said about the Kashmir plebiscite. As he put his however it in our incredible open door in Kashmir he may be deficient in energy, yet he additionally thought that it is so hard to acknowledge that individuals of Kashmir had effectively casted a ballot to coordinate themselves into India based on profoundly speculate 1957 and 1962 races. Why not allow the Kashmiris a genuine opportunity to offer their viewpoints and perspectives? On the off chance that India was so certain of their desires, what risk would there be? Jayaprakash Naray an like wise said, we much contended by the Indian side against any concessions to Pakistan in Kashmir. Indian defenders from very in beginning phase in the question had asserted that to allow any division on the province of Jammu and Kashmir's for "Two Nation" hypothesis yet additionally would give the sign to a significant flare-up of common revolting all through the Indian Republic, the preface to the breaking down of the Indian mainstream express (a contention which is as yet being brought up in India in 1991). However, he additionally characterized and brought up; this was surely a senseless contention. It inferred that the Indian States were held together by compelling them instead of by a feeling of normal ethnicity. On the off chance that it is valid, the Indian Union would in reality be close to a despot; and its popular government would be an empty farce.

The death of Nehru without a doubt denoted a final turning point throughout the entire existence of the Kashmir question, however this was not desperately. Articulation of Indo-Pakistani kindness arrangements were made for a highest point meeting between president Ayub Khan and new Indian P.M that took place in 1964. 


\section{Conclusion}

Kashmir has a historical legacy in the subcontinent. Where individuals of this nation is step by step battling and forfeiting for the opportunity and autonomy to carry on with a cheerful and free life. Indian military occupied Kashmir on 22 ${ }^{\text {nd }}$ October, 1947. Pakistan controls around 33\% of Kashmir (Azad Kashmir and Gilgit Baltistan) where India controls the rest part or remaining part (Kashmir valley, Jammu and Ladakh) before 1947 Kashmir was controlled by Mughal Empire in 1589 A.D, Kashmir in the set of experiences has never governed by the Kashmiri. During the following eras the rulers who controlled Kashmir along with their men: Mughals (1589 A.D), Afghans (1753-1819), Sikhs (18191846) and Dogras (1846-1947).

This is the historical backdrop of Kashmir. Until now Kashmir isn't sovereign that is the reason it isn't considered as a state. Pakistan accepts that Kashmir was misguidedly or lawfully surrendered to India by a not ruler address individuals. Since a greater part of the Muslims states needs or have a place with Pakistan, they trust Kashmir ought to have a place with them. Kashmir has colossal significance to Pakistan for key reasons. The lockdown authoritatively began on fifth August 2019. Individuals of Kashmir need freedom. Naya Pakistan Manifesto is expressed for the privileges of ladies of Kashmir and outcasts. This idea is working for the assurance of privileges of ladies and outcasts. Indian Army is mistreating and tormenting individuals of Kashmir this is the fundamental explanation that they need equity and opportunity.

Kashmiriyat is expressed for individuals of Kashmir, there are various networks of individuals who are living in Kashmir and this is known as kashmiriyat. The start of agent government in India was administrated Jammu and Kashmir. The Kashmiri issue is a long standing bone of conflict. Sheikh Abdullah is known as "The Lion of Kashmir". Kashmir is taken care of Indian military they don't have sort of interest with individuals of Kashmir. Unlimited discussions toward the finish of November, 1962, the Britain and The United States sent mission to New Delhi which drove separately by Duncan Sandys, the Secretary of States for Common Wealth Relations and furthermore Averell Harriman, he is the aide Secretary of the State for far Eastern Affairs to figure out what 
military assist India with requiring. Kashmir is known as "Valley of Beauty".

Not only men but Kashmiri Women also drive for harmony and demilitarization. Ladies of Kashmir and furthermore offspring of Kashmir they are undependable in this state, Kashmir. Kashmir is the state where all individuals are losing their lives. However, it doesn't matters to India. They need Kashmir at any expense and furthermore through any way. Individuals of Kashmir say that they don't need compassion of states and their Ministers they need just equity and opportunity they need to end control of India and they need to send a glad life. On fifteenth August 1947, Maharaja Hari Singh Regime sanctioned a stop concurrence with the public authority of Pakistan. Pakistan was turned into an autonomous state on fourteenth August 1947 and India was free on fifteenth August 1947, however, Kashmiris are until the present time hanging tight for their fundamental rights and power. Until 1947 , Jammu and Kashmir stayed a free territory. But due to the current situation of political crisis, the future of Kashmir is unpredictable. 


\section{References}

1. Bose, S. (2003). Kashmir: Roots of Conflict, Paths to Peace. London: Harvard University Press.

2. Brown, J. M. (2003). Nehru: A Political Life. New Haven: Yale University Press.

3. Campbell-Johnson, A. (1985). Mission with Mountbatten. London: Hamilton.

4. Jalal, Ayesha.(1985). The Sole Spokesman: Jinnah, the Muslim League and the Demand for Pakistan. Cambridge: Cambridge University Press.

5. Peer, Basharat. (2010). Curfewed Night: A Frontline Memoir of Life, Love, and War in Kashmir.London: Harper Press.

6. Schofield, Victoria.(1996). Kashmir in the Crossfire. London: I. B. Tauris.

7. Ta lbot, I. (2016). A History of Modern South Asia: Politics, States and Diasporas. London: Yale University Press. 